\title{
PENERAPAN TOGAF ARCHITECTURE DEVELOPMENT METHOD PADA SISTEM INFORMASI TRACER STUDY BERBASIS WEB
}

\author{
Nika Punggarawati ${ }^{1}$ Cecep Kurnia Sastradiparaja ${ }^{2}$ Falentino Sembiring ${ }^{3}$ \\ ${ }^{1,2,3}$ Sistem Informasi, Universitas Nusa Putra \\ Jl.Raya Cibolang No.21 Sukabumi \\ punggaranika95@gmai.com ${ }^{1}$, cecep.kurnia@nusaputra.ac.id ${ }^{2}$, falentino.sembiring@nusaputra.ac.id ${ }^{3}$
}

\begin{abstract}
ABSTRAK
Alumni merupakan komponen terpenting institusi dalam meningkatkan citra perguruan tinggi. Salah satu aspek penilaian kredibilitas suatu perguruan tinggi pada persepsi publik dan institusi dapat dilihat dari relevansi antara lulusan, bidang studinya dan jenis pekerjaannya. Kurikulum dan proses belajar mengajar pada institusi pendidikan dapat dinilai baik apabila setiap lulusannya dapat diterima pada pasar kerja dan sesuai dengan kebutuhan pengguna lulusan, sehingga untuk menuju taraf tersebut pergururuan tinggi harus mengetahui tren pasar dan kebutuhan pengguna lulusan dengan mengikutsertakan keterlibatan dari alumni dan pengguna lulusan untuk mendapatkan informasi umpan balik. Di dalam pengelolaan informasi kegiatan tracer study dengan mengedapankan teknologi informasi dan komunikasi menjadi suatu keharusan, dimana pesatnya perkembangan TIK dan kesibukan aktivitas stakeholder menjadi aspek yang tidak bisa diabaikan. Tujuan dilaksanakannya penelitian ini adalah untuk menghasilkan artistektur enterprsise dan prototype sistem informasi tracer study dengan memanfaatkan kerangka kerja TOGAF ADM melalui 4 (empat) fase yaitu Architecture Vision, Bussiness Architecture, Information System Architecture, Technology Architecture. Metode penelitian yaitu deskriptif dengan pendekatan kuantitatif. Dari hasil penelitian diperoleh arsitektur enterprise dan prototipe tracer study yang diharapkan dapat menjadi sumber acuan dalam implementasi dan dapat mempermudah pengelolaan dan penelusuran lulusan, dengan mempertimbangkan aspek bisnis, aplikasi, teknologi dan jaringan, efektivitas dan efisiensi tata kelola sitem informasi tracer study AMIK XYZ.
\end{abstract}

Kata kunci: Tracer Study, Perguruan tinggi, TOGAF ADM, Alumni, Architecture Enterprise

\section{PENDAHULUAN}

\subsection{Latar Belakang}

Tracer study adalah studi pelacakan lulusan perguruan tinggi, dimana tracer study merupakan pilar yang sangat penting dalam konteks meninjau kinerja sebuah institusi. Adapun dalam pelacakan lulusan diharapkan dilaksanakan secara institusional di level perguruan tinggi, bukan dilevel program studi, departemen atau fakultas. Selanjutnya tracer studi ini ditargetkan pada lulusan yang sudah 2 tahun lulus, jadi kohor yang ditarget adalah kohor yang sudah lulus 2 tahun pada saat pelaksanaan survey. Kemudian diharapkan tracer study yang dilaksanakan harus mengikuti desain, metodologi dan instrumen yang terstandarisasi supaya bisa dilakukan kompilasi dan komparasi data ditingkat nasional. Penelitian tracer study ini memiliki lima tipe berdasarkan beberapa karakteristik yaitu: target populasi, situasi referensi, periode referensi, pengumpulan informasi, titik masuk [1].

Berdasarkan hasil penelitian yang dilakukan penulis bahwa AMIK XYZ dalam pengelolaan tracer study masih manual dan belum rutin dalam pelaksanaannya mengingat belum memiliki prosedur kegiatan dan acuan yang jelas dalam implementasi. Pengelolaan tracer study masih dilakukan oleh program studi dan dilakukan berdasarkan waktu dan kebutuhan serta belum adanya sistem informasi yang terintegrasi.

Dari beberapa fakta permasalahan yang telah dijelaskan dan mengingat begitu pesatnya perkembangan teknologi informasi dan komunikasi maka sudah menjadi suatu 
keharusan dalam pelaksanaan tracer study dilakukan dengan mempertimbangakn aspek bisnis, aplikasi, teknologi dan prosedur yang jelas untuk mempermudah dalam mendukung aktivitas bisnis institusi.

Untuk proses penyelesaian masalah yang terjadi, maka penulis mencoba membuat perencanaan arsitektur pada sistem informasi tracer study dengan metode Togaf ADM yang merupakan salah satu solusi yang ditawarkan untuk memenuhi kebutuhan institusi AMIK $\mathrm{XYZ}$ dalam pengadaan pedoman arsitektur dan prototype sistem informasi tracer study.

Sesuai dengan uraian di atas maka dibuatlah sebuah topik, dengan judul "Penerapan Togaf Architecture Development Method (ADM) Pada Sistem Informasi Tracer Study Perguruan Tinggi (Studi Kasus : AMIK XYZ)".

\subsection{Penelitian Terkait}

Muhammad Rizka, dari Politeknik Negeri Lhokseumawe (2018) dengan judul "Analisis Dan Perancangan Sistem Informasi Tracer Study Berbasis WEB". Penelitian ini bertujuan untuk membangun sistem informasi tracer study berbasis web yang dapat digunakan untuk memperoleh informasi alumni politeknik negeri Lhokseumawe dengan menggunakan metode waterfall, framework code igniter dan database MySQL [2].

Ahmad Kamil Almasyhur, dari Universitas Brawijaya (2018) dengan judul "Pengembangan Aplikasi Mobile Tracer Study Menggunakan Platform Android". Penelitian ini bertujuan untuk menegembangkan Sistem Tracer Study yang dapat menghubungkan antara satu alumni dan alumni yang lain. Alumni dapat memberikan informasi pendidikan dan pekerjaan alumni saat ini, alumni juga dapat saling memberikan informasi tentang lowongan pekerjaan kepada alumni yang lain. Penelitian ini menggunakan SDLC prototype dengan menggunakan platform firebase dan Android [3].

Kartika Indayani, dari Institut Sains \& Teknologi AKPRIND (2016), dengan judul "Aplikasi Mobile Alumni Center". Penelitian ini bertujuan membangun aplikasi mobile yang membantu proses pendataan alumni dilengkapi dengan fitur tracer study. Aplikasi yang dibangun berbasis android dan web dengan model client server, dimana aplikasi web untuk administrator dan aplikasi mobile untuk para alumni. Data menggunakan sistem basisdata eksternal MySQL dengan dukungan bahasa pemrograman PHP dan protokol json [4].

Dikot Sugeng Astomo, dari Universitas Komputer Indonesia (2017), dengan judul "Pembangunan Aplikasi Pencarian Alumni Berbasis Android dengan Memanfaatkan API Sosial Media”. Penelitian ini bertujuan membangun aplikasi pencari alumni berbasis android dengan memanfaatkan API sosial media [5].

\subsection{Tinjauan Pustaka \\ 1.3.1 Sistem}

Sistem adalah suatu jaringan kerja dari prosedur-prosedur yang saling berhubungan, berkumpul bersama untuk melakukan suatu kegiatan atau menyelesaikan suatu sasaran yang tertentu. [6]

\subsubsection{Informasi}

Informasi adalah kumpulan data yang telah diolah menjadi bentuk yang lebih berarti dan berguna bagi penerimanya untuk mengambil keputusan masa kini maupun masa yang akan datang. [6].

\subsubsection{Sistem Informasi}

Sistem informasi adalah suatu sistem di dalam suatu organisasi yang mempertemukan kebutuhan pengolahan transaksi harian, mendukung operasi, bersifat manajerial dan kegiatan strategi dari suatu organisasi dan menyediakan pihak luar tertentu laporanlaporan yang diperlukan. [6].

\subsubsection{Tracer study}

Penelusuran lulusan (tracer study) adalah merupakan salah satu cara untuk mendapatkan informasi tentang berapa jumlah lulusan perguruan tinggi yang telah mendapatakan pekerjaan yang sesuai dengan relevansi pendidikannya. Hasil tracer study juga dapat dipergunakan perguruan tinggi untuk mengetahui keberhasilan proses pendidikan yang telah dilakukan terhadap anak didiknya. Bahkan dalam program hibah kompetisi maupun akreditasi selalu mempersyaratkan adanya data hasil dari tracer study tersebut melalui parameter masa tunggu lulusan, persen lulusan yang sudah bekerja dan penghasilan yang diperoleh. Tracer study merupakan 
pendekatan yang memungkinkan institusi pendidikan tinggi memperoleh informasi tentang kekurangan yang mungkin terjadi dalam proses pendidikan dan proses pembelajaran dan dapat merupakan dasar untuk perencanaan aktivitas untuk penyempurnaan dimasa mendatang [7].

\subsubsection{Enterprise}

Enterprise diartikan sebagai semua kumpulan organisasi yang memiliki sekumpulan tujuan. Enterprise dapat merupakan sebuah agen pemerintahan, sebuah korporasi keseluruhan, divisi korporasi, departemen tunggal atau sebuah rantai organisasi yang berhubungan tetapi berjauhan secara geografis [8].

\subsubsection{Arsitektur (Architecture)}

Sekumpulan komponen rancangan yang penting mempunyai hubungan antar lingkungan sistem sehingga evaluasi untuk dasar sistem suatu organisasi kedepannya dapat dirumuskan dan dijalankan sesuai dengan gambaran yang telah dibuat [8].

\subsubsection{Enterprise Architecture (EA)}

Enterprise Architecture adalah blueprint organisasi yang menentukan bisnis, informasi dan teknologi yang digunakan agar tercapai misi organanisasi [8].

\subsubsection{TOGAF (The Open Group Architecture Framework) \\ The Open Group Architecture} Framework.(TOGAF) merupakan kerangka arsitektur yang menyediakan method dan tools untuk membantu dalam proses penerimaan (Acceptance), produksi, penggunaan, dan pemeliharaan suatu arsitektur enterprise. Hal ini berdasarkan suatu model proses yang iteratif, didukung oleh praktik baik (best practices) dan dapat digunakan kembali (reusable) dari suatu kumpulan aset-aset arsitektur [8].

TOGAF Architecture Development Method (ADM) menyediakan pengujian dan proses-proses yang berulang untuk mengembangkan arsitektur. ADM meliputi: membuat sebuah kerangka arsitektur, mengembangkan isi arsitektur, transisi, dan realisasi pengelolaan arsitektur. Keseluruhan aktivitas tersebut menjadi output aktivitas lainnya dalam sebuah siklus yang iteratif secara terus menerus menjadi arsitektur yang terdefinsi dan direalisasikan. Memungkinkan organisasi mentransformasi enterprise-nya dalam suatu pola terkendali untuk merespon tujuan-tujuan dan peluang-peluang bisnis.

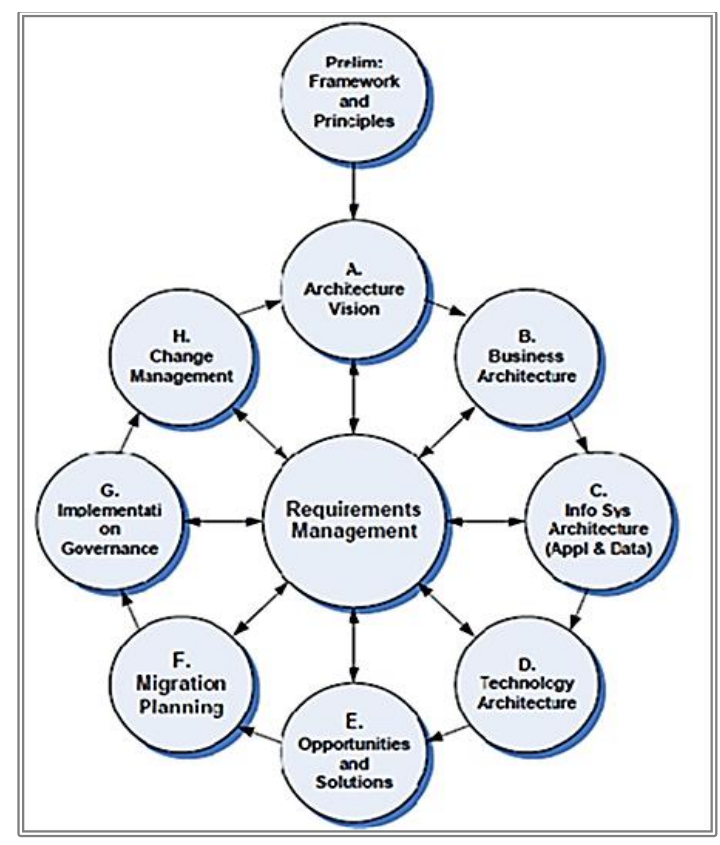

Gambar 1.1 ADM TOGAF ( The Open, 2009)

Tahapan dari TOGAF ADM bisa dijelaskan sebagai berikut (Open Group 2009): Preliminary Framework and Priciple (Tahapan A). Architecture Vision (Tahapan B). Business Architecture (Tahapan C). Information System Architecture (Tahapan D) Technology Architecture (Tahapan E). Opportunities and Solution (Tahapan F). Migration Planning (Tahapan G). Implementation Governance (Tahapan H). Architecture Change Management (Tahapan I) [8].

\subsubsection{Website}

Website adalah fasilitas internet yang menghubungkan dokumen dalam lingkup lokal maupun jarak jauh. Dokumen pada website disebut dengan web page dan link dalam website memungkinkan pengguna bisa berpindah dari satu page ke page lain (hypertext), baik diantara page yang disimpan dalam server yang sama maupun server diseluruh dunia [9].

\subsubsection{METODE PENELITIAN}


Berikut merupakan gambaran mengenai kerangka penelitian yang dilakuakan terhadap penerapan sistem tracer study.

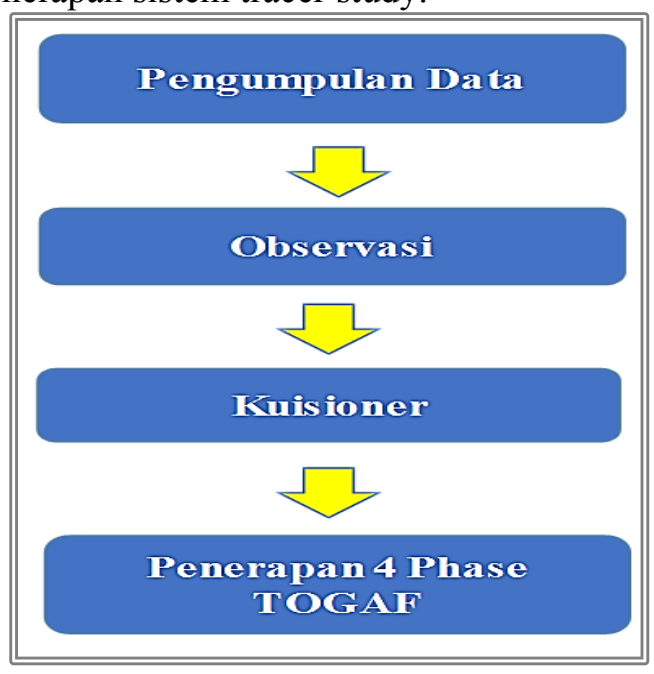

Gambar 1.2 Kerangka Penelitian

\subsubsection{Kebutuhan Hardware dan Software}

1. Kebutuhan Hardware
a) PC dengan OS min windows XP.
b) RAM min $1 \mathrm{~GB}$.
c) HDD $\min 320 \mathrm{~GB}$.
d) Modem/Wifi/Koneksi Internet.

2. Kebutuhan Software
a) XAMPP.
b) Notepad ++ / Sublime Editor.
c) Google Chrome.

\section{HASIL DAN ANALISIS}

Pada bab pembahasan hasil dan analisis mendefinisikan tahapan proses perancangan arsitektur enterprise berdasarkan struktur desain TOGAF ADM, yaitu:

\subsection{Preliminary Phase.}

Sebagai salah satu aktivitas bisnis AMIK XYZ, kegiatan tracer study belum dilaksanakan secara rutin. Adapun untuk pelaksanaan kegiatan tracer study masih dilakukan secara manual oleh setiap program studi masing-masing.

AMIK XYZ memiliki lembaga pendukung dalam pengelolaan informasi pekerjaan bagi alumninya yaitu Bursa Kerja Khusus (BKK) dimana tugas pokok dan fungsinya adalah menjalin kemitraan dengan dunia industri telah tersebar di berbagai sektor industri baik di dalam negeri maupun di luar negeri.
Adapun konfirmasi pemerintah dan dukungan framework yang berkenaan dengan tracer study sebagai contoh tertuang pada surat edaran Ristekdikti yaitu: Surat Edaran Nomor 0965/K3/KM/2017, perihal Pelaksanaan Tracer study Tingkat Nasional dan Surat Direktur Jenderal Pembelajaran dan Kemahasiswaan Nomor 313/B/SE/2017, tentang Pelaksanaan Tracer Study di Tingkat Perguruan Tinggi.

Adapun konfirmasi dan dukungan internal institusi AMIK XYZ, adalah adanya keinginan untuk memiliki arsitektur, teknologi dan sistem informasi yang komprehensif dan terintegrasi pada pengelolaan Tracer Studi, sehingga didalam pelaksanaannya bisa dilakukan pada tingkat institusi AMIK XYZ.

Dalam penerapan Togaf ADM, penulis hanya berfokus kepada 4 siklus tahapan pengembangan arsitektur, yaitu: Architecture Vision, Business Architecture, Information System Architecture, dan Technology Architecture.

\subsection{Requirement Management}

Pada tahapan ini adalah menentukan suatu kebutuhan proses untuk enterprise architecture. Skenario bisnis menjadi resources utama yang harus dikembangkan dalam tahapan ini. Skenario bisnis harus mencakup core businesss, process business, dan permasalahan (issue) organisasi.

\subsubsection{Bisnis Utama (Core Business)}

Bisnis utama dari AMIK XYZ adalah menyelengarakan pendidikan dengan memperhatikan penjaminan mutu lulusan, sehingga mampu menghadirkan lulusan yang berkualitas dan memiliki daya saing pada dunia usaha dan industri, baik skala nasional dan internasional. Sebagai indikator pencapaian dari hal ini adalah:

1) Penyelenggaraan Program Nasional

2) Penyelenggaraan Program Internasional, diantaranya;

a) Program penelitian, pekerjaan, magang dan beasiswa luar negeri yang diselenggarakan Kantor Urusan Internasional (KUI). 
b) Melakukan kerja sama antar universitas, dengan mendatangkan dosen dari luar negeri yang sesuai dengan perkembangan terbaru di dunia pendidikan internasional.

\subsubsection{Proses Bisnis}

Proses bisnis untuk tracer study AMIK XYZ secara terperinci sudah disebutkan seperti tertera pada gambar 2.1 berikut ini:

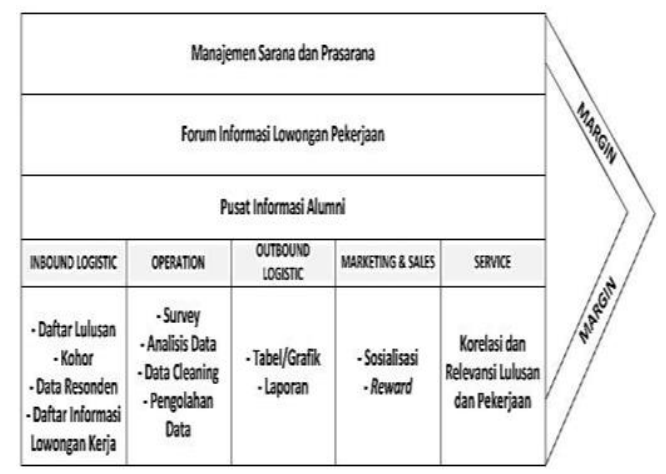

Gambar 2.1 Value Chain Tracer Study

\subsubsection{Issue Organisasi}

Berdasarkan dari hasil penelitian yang dilakukan pada proses bisnis sebelumnya. Maka diperoleh gambaran permasalahan yang dialami oleh AMIK XYZ, yang kemudian akan dijelaskan pada tabel 2.1 dibawah ini.

Tabel 2.1 Permasalahan AMIK XYZ

\begin{tabular}{|l|l|l|l|}
\hline No & $\begin{array}{c}\text { Aktivitas } \\
\text { Bisnis }\end{array}$ & Permasalahan & Tolak Ukur \\
\hline 1. & $\begin{array}{l}\text { Pendataan } \\
\text { Alumni }\end{array}$ & $\begin{array}{l}\text { Tidak adanya } \\
\text { sistem } \\
\text { informasi } \\
\text { pengelolaan } \\
\text { tracer study }\end{array}$ & $\begin{array}{l}\text { Lambatnya } \\
\text { dalam } \\
\text { pengelolaan } \\
\text { tracer study }\end{array}$ \\
\hline 2. & $\begin{array}{l}\text { Forum } \\
\text { Alumni }\end{array}$ & $\begin{array}{l}\text { Tidak adanya } \\
\text { forum diskusi } \\
\text { dan bertukar } \\
\text { informasi antar } \\
\text { alumni }\end{array}$ & $\begin{array}{l}\text { Sulitnya dalam } \\
\text { bertukar } \\
\text { informasi baik } \\
\text { pihak } \\
\text { manajemen } \\
\text { AMIK XYZ } \\
\text { atau antar } \\
\text { sesama alumni }\end{array}$ \\
\hline 3. & $\begin{array}{l}\text { Manajemen } \\
\text { Alumni }\end{array}$ & $\begin{array}{l}\text { Tidak adanya } \\
\text { arsitektur dan } \\
\text { prosedur } \\
\text { dalam } \\
\text { pelaksanaan } \\
\text { tracer study }\end{array}$ & $\begin{array}{l}\text { Pelaksanaan } \\
\text { Tracer Study } \\
\text { bersifat } \\
\text { insidental dan } \\
\text { disesuaikan } \\
\text { dengan } \\
\text { kebutuhan saja. }\end{array}$ \\
& & & \\
& & &
\end{tabular}

\begin{tabular}{|l|l|l|l|}
\hline 5. & Rekomendasi- & Tidak adanya & Informasi \\
Pekerjaan & Informasi & lowongan kerja \\
& lowongan \\
yang berbasis & yang \\
& rekomendasi \\
& untuk alumni \\
& & $\begin{array}{l}\text { disediakan oleh } \\
\text { lembaga } \\
\text { pendukung } \\
\text { yaitu BKK }\end{array}$ \\
& & \\
& &
\end{tabular}

\subsection{Phase A. Architecture Vision}

\subsubsection{Profil Perguruan Tinggi}

Lembaga Pendidikan Profesi XYZ yang merupakan cikal bakal lahirnya AMIK XYZ berdiri tanggal 2 Mei 1992, dengan visi sebagai berikut:

"Menjadi Lembaga Pendidikan Tinggi yang Menghasilkan Sumber Daya Manusia yang Unggul, Mandiri, dan Berkarakter". Adapun struktur organisasinya seperti pada gambar 2.2 dibawah ini:

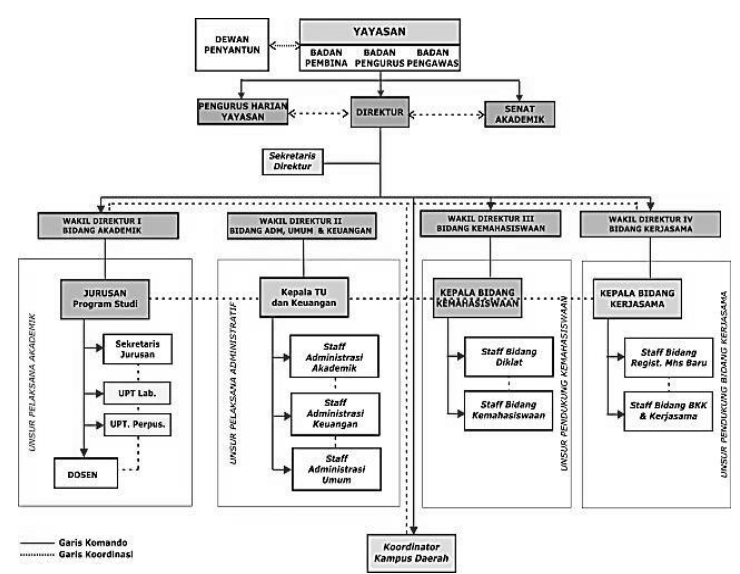

Gambar 2.2 Struktur Organisasi AMIK XYZ

\subsubsection{Kondisi Arsitektur Saat Ini}

Koleksi teknologi informasi yang ada pada unit organisasi pelaksana tracer study saat ini umumnya menggunakan aplikasi perkantoran seperti ms. office, media sosisal, e-mail, adapun data-data terkait diuraikan dalam bentuk tabel 2.2 berikut ini:

Tabel 2.2 Koleki TI pada pelaksanaan tracer study

\begin{tabular}{|c|c|c|c|}
\hline No & $\begin{array}{c}\text { Teknologi } \\
\text { Informasi }\end{array}$ & Data & Unit Pelaksana \\
\hline 1. & Ms. Excel & Data Alumni & $\begin{array}{c}\text { Staf } \\
\text { Kemahasiswaan } \\
\text { dan Alumni }\end{array}$ \\
\hline 2. & $\begin{array}{c}\text { Website AMIK } \\
\text { XYZ } \\
\text { http://www.xyz } \\
\text { ac.id }\end{array}$ & $\begin{array}{c}\text { Sosialisasi } \\
\text { Tracer study }\end{array}$ & $\begin{array}{c}\text { Manajer } \\
\text { Kemahasiswaan } \\
\text { dan alumni }\end{array}$ \\
\hline 3 & Google form & Data Sebaran & -Staf \\
\hline
\end{tabular}




\begin{tabular}{|c|c|c|c|}
\hline & Kuesioner & $\begin{array}{c}\text { Kemahasiswaa } \\
\text { n dan alumni } \\
\text {-Staf Magang }\end{array}$ \\
\hline 4 & $\begin{array}{c}\text { Media Sosial } \\
\text { Facebook } \\
\text { http://www.fac } \\
\text { ebook.com/pag } \\
\text { es/amik-xyz }\end{array}$ & $\begin{array}{c}\text { Informasi dan } \\
\text { sosialisasi } \\
\text { sebaran } \\
\text { kuesioner }\end{array}$ & $\begin{array}{c}\text {-Staf } \\
\text { Kemahsiswaan } \\
\text { dan alumni }\end{array}$ \\
\hline
\end{tabular}

\subsection{Phase B. Business Architecture.}

Pada tahap bisnis arsitektur merupakan perancangan arsitektur terhadap semua proses bisnis yang memiliki keterkaitan terahadap proses tracer study. Tahapan ini meliputi penjabararan stake holder yang terkait dengan tracer study, Gap Analysys terhadap arsitektur bisnis secara umum, gap analysis proses bisnis tracer study saat ini dan usulan perancangan proses bisnis tracer study.

\subsubsection{Stakeholder Tracer study}

Hubungan dari stakeholder proses tracer study dengan berbagai fungsi bisnis dapat digambarkan dengan menggunakan pemodelan use case diagram sebagai berikut:

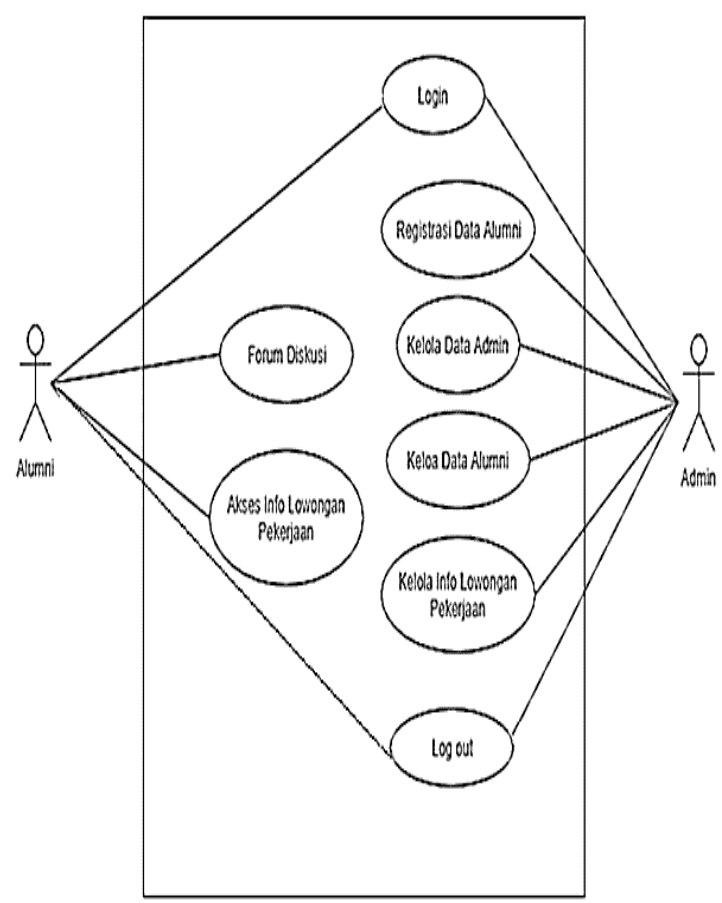

Gambar 2.3 Usecase Stakeholder Tracer Study

\subsubsection{Gap Analysis Arsitektur Bisnis secara umum}

Pada tahap ini dilakukan Gap Analysis pada arsitektur bisnis yang sedang berjalan di AMIK XYZ, hal ini dilakukan sebagai pertimbangan dalam pencapaian target dari perancangan arsitektur bsnis yang sesuai dengan kriteria yang harapkan. Berikut merupakan daftar Gap Analysis arsitektur bisnis pada AMIK XYZ dalam bidang teknologi informasi, yang digambarkan pada tabel 2.3 berikut ini:

Tabel 2.3 Gap Analysis Arsitektur Bisnis Terkait TI Tracer Study

\begin{tabular}{|c|c|c|c|}
\hline No & $\begin{array}{c}\text { Arsitektur Bisnis } \\
\text { saat ini } \\
\text { (existing) }\end{array}$ & $\begin{array}{l}\text { Usulan } \\
\text { Arsitektur } \\
\text { Bisnis } \\
\text { (solution) }\end{array}$ & $\begin{array}{l}\text { Arsitektur } \\
\text { Bisnis } \\
\text { Mendatang } \\
\text { (future) }\end{array}$ \\
\hline 1 & $\begin{array}{l}\text { Dalam } \\
\text { menjalankan } \\
\text { bisnis pada tracer } \\
\text { study, AMIK XYZ } \\
\text { belum sepenuhnya } \\
\text { memanfaat } \\
\text { teknologi } \\
\text { informasi sebagai } \\
\text { kebutuhan utama }\end{array}$ & $\begin{array}{l}\text { Melakukan } \\
\text { perancangan } \\
\text { penerapan } \\
\text { teknologi } \\
\text { informasi } \\
\text { terhadap } \\
\text { proses bisnis } \\
\text { tracer study } \\
\text { AMIK XYZ }\end{array}$ & $\begin{array}{l}\text { AMIK XYZ } \\
\text { memiliki } \\
\text { prototype } \\
\text { arsitektur } \\
\text { teknologi } \\
\text { informasi } \\
\text { pada bisnis } \\
\text { tracer study }\end{array}$ \\
\hline 2. & $\begin{array}{l}\text { aktivitas bisnis } \\
\text { teknologi } \\
\text { informasi pada } \\
\text { tracer study belum } \\
\text { sepenuhnya } \\
\text { tertangani secara } \\
\text { khusus seperti } \\
\text { halnya eksistensi } \\
\text { CDC. }\end{array}$ & $\begin{array}{l}\text { Membuat } \\
\text { perencanaan } \\
\text { pembentukan } \\
\text { lembaga } \\
\text { pendukung } \\
\text { CDC yang } \\
\text { memiliki } \\
\text { tugas pokok } \\
\text { dan fungsi } \\
\text { khusus } \\
\text { mengelola } \\
\text { teknologi } \\
\text { informasi } \\
\text { tracer study } \\
\end{array}$ & $\begin{array}{l}\text { Terbentuknya } \\
\text { Direktorat } \\
\text { atau lembaga } \\
\text { pendukung } \\
\text { CDC yang } \\
\text { dapat } \\
\text { mendukung } \\
\text { lembaga BKK }\end{array}$ \\
\hline 3. & $\begin{array}{l}\text { Belum memiliki } \\
\text { sepenuhnya } \\
\text { prosedur-prosedur } \\
\text { kerja terhadap } \\
\text { aktivitas bisnis } \\
\text { teknologi } \\
\text { informasi pada } \\
\text { tracer study }\end{array}$ & $\begin{array}{l}\text { Melakukan } \\
\text { peracangan } \\
\text { prosedur kerja } \\
\text { dalm } \\
\text { pengelolaan } \\
\text { teknologi } \\
\text { informasi } \\
\text { pada tracer } \\
\text { study }\end{array}$ & $\begin{array}{l}\text { Adanya } \\
\text { arsitektur } \\
\text { enterprise } \\
\text { pengelolaan } \\
\text { teknologi } \\
\text { informasi } \\
\text { pada tracer } \\
\text { study }\end{array}$ \\
\hline
\end{tabular}

\subsubsection{Gap Analysis proses bisnis tracer study saat ini}

Dari hasil identifikasi Gap Analysis proses bisnis tracer study saat ini (existing) adalah:

1. Dalam studi pelacakan alumni belum terkomputerisasi dan dilakukan oleh masing-masing program studi secara informal dan insidental. 
2. Belum efektif dapat memperoleh feedback baik dari alumni maupun pengguna lulusan.

3. Belum efektifnya penyebaran informasi yang dibutuhkan para stakeholder terkait pengelolaan alumni

4. Lembaga BKK hanya memberikan Informasi lowongan kerja bersifat umum.

Dalam alur perancangan proses bisnis secara umum pada sistem tracer study akan digambarkan pada gambar flowchart 2.4 sebagai berikut:

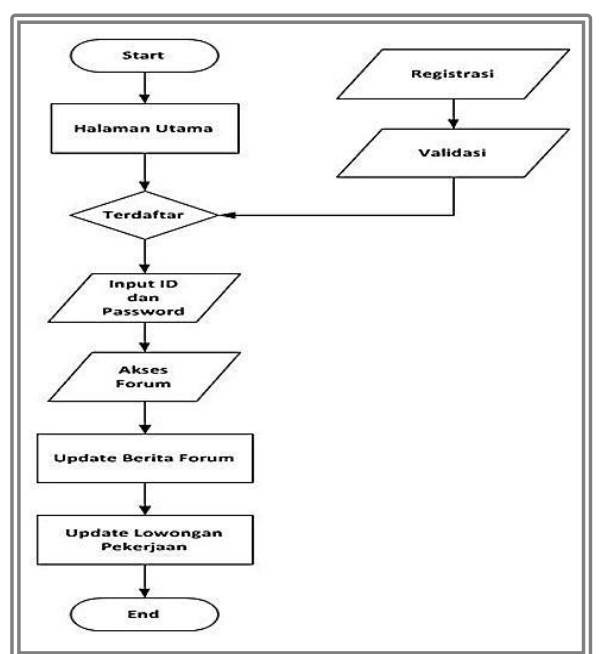

Gambar 2.4 Flowchart Usulan Proses Pengelolaan Tracer Study

\subsubsection{Bagan Hierarki Fungsi}

Sesuai dengan proses bisnis yang telah dijelaskan, berikut ini merupakan hierarki fungsi yang telah didekomposisikan dalam bentuk bagan tabel 2.4 berikut:

Tabel 2.4 Bagan Hierarki Fungsi

\section{Database Alumni}

1.1 Pendaftaran Alumni

1.2 Registrasi Alumni

1.3 Pendataan data diri alumni

2. Pusat informasi alumni

2.1 Memberikan informasi terkini bagi alumni

2.2 Memberkan wadah untuk saling bertukar informasi

\section{Manajemen sarana dan prasarana}

3.1 Pengawasan dan evaluasi para alumni

3.2 Pelaporan pengadaan

3.3 Perencanaan pemanfaatan sarana dan prasarana

4. Forum informasi lowongan pekerjaan

4.1 Memberikan info lowongan pekerjaan secara berkala dan lengkap

4.2 Pengecekan berapa banyak alumni yang mendapat pekerjaan

\section{Manajemen Kuesioner}

5.1 Pengelolaan Data Kuesioner

\subsection{Phase C. Information System Architectur}

Pada tahap arsitektur sistem informasi meliputi perancangan arsitektur sistem informasi tracer study dengan melakukan pembagian 2 tahapan yaitu perancangan arsiterktur data dan perancangan arsitektur aplikasi.

\subsubsection{Gap Analysis Arsitektur Sistem Informasi}

Gap Analysis terhadap sistem informasi dilakukan untuk memperoleh hasil perancangan sistem informasi yang memenuhi kriteria yang diharapkan. Pendefinisian dari gap analisys asrsitektur sistem informasi dapat dilihat dalam bentuk tabel 2.5 berikut ini:

Tabel 2.5 GAP Analisys Arsitektur Sistem Informasi

\begin{tabular}{|c|c|c|c|}
\hline & \begin{tabular}{|c|c|} 
Arsitektur & Sistem \\
Informasi Saat \\
ini
\end{tabular} & $\begin{array}{c}\text { Solusi } \\
\text { Arsitektur } \\
\text { Sistem } \\
\text { Informasi }\end{array}$ & $\begin{array}{c}\text { Target di } \\
\text { masa } \\
\text { mendatang } \\
\text { (Future) }\end{array}$ \\
\hline 1. & $\begin{array}{l}\text { Belum ada } \\
\text { database tracer } \\
\text { study. }\end{array}$ & $\begin{array}{l}\text { Membuat } \\
\text { perancangan } \\
\text { database yang } \\
\text { dapat diakses } \\
\text { pihak akademi } \\
\text { dan alumni. }\end{array}$ & $\begin{array}{l}\text { Tersedianya } \\
\text { database } \\
\text { tracer study } \\
\text { untuk semua } \\
\text { stakeholder } \\
\text { tracer study. }\end{array}$ \\
\hline & $\begin{array}{l}\text { Pengolahan data } \\
\text { tracer study } \\
\text { masih masih } \\
\text { menggunakan } \\
\text { aplikasi } M s . \\
\text { Office. }\end{array}$ & $\begin{array}{l}\text { Merancang } \\
\text { sistem } \\
\text { informasi } \\
\text { tracer study }\end{array}$ & $\begin{array}{l}\text { Adanya sistem } \\
\text { informasi } \\
\text { untuk } \\
\text { pengelolaan } \\
\text { terkait tracer } \\
\text { study }\end{array}$ \\
\hline & \begin{tabular}{|l|} 
Belum ada \\
sistem informasi \\
yang secara \\
khusus \\
menangani \\
informasi \\
lowongan kerja
\end{tabular} & \begin{tabular}{|l} 
Merancang \\
sistem \\
informasi \\
lowongan kerja \\
sebagai \\
pendukung \\
sistem \\
informasi \\
tracer study
\end{tabular} & $\begin{array}{l}\text { Tersed } \\
\text { sistem } \\
\text { inform } \\
\text { lowong } \\
\text { pekerja } \\
\text { melenk } \\
\text { pada si } \\
\text { inform } \\
\text { tracer }\end{array}$ \\
\hline & $\begin{array}{l}\text { sistem informas } \\
\text { yang } \\
\text { diperuntukan } \\
\text { stakeholder }\end{array}$ & $\begin{array}{l}\text { Melakukann } \\
\text { perancangan } \\
\text { sistem } \\
\text { informasi untuk } \\
\text { akses }\end{array}$ & $\begin{array}{l}\text { Tersedianya } \\
\text { sistem } \\
\text { informasi } \\
\text { dengan akses } \\
\text { stakeholder }\end{array}$ \\
\hline
\end{tabular}




\begin{tabular}{|c|c|c|c|}
\hline & tracer study & $\begin{array}{l}\text { stakeholder } \\
\text { tracer study }\end{array}$ & $\begin{array}{l}\text { sesuai } \\
\text { peruntukannya. }\end{array}$ \\
\hline 5. & $\begin{array}{l}\text { Belum ada } \\
\text { sistem informasi } \\
\text { berupa media } \\
\text { forum diskusi } \\
\text { untuk } \\
\text { stakeholder } \\
\text { tracer study }\end{array}$ & $\begin{array}{l}\text { Merancang } \\
\text { sistem forum } \\
\text { diskusi yang } \\
\text { mewadahi } \\
\text { komunikasi } \\
\text { antar } \\
\text { stakeholde }\end{array}$ & $\begin{array}{l}\text { Tersedianya } \\
\text { forum diskusi } \\
\text { sebagai } \\
\text { pendukung } \\
\text { sistem } \\
\text { informasi } \\
\text { tracer study. }\end{array}$ \\
\hline
\end{tabular}

\subsubsection{Arsitektur Data}

Pemodelan arsitektur data dibuat dengan class diagram. Adapun Tahap dalam pendefinisan kelas data yaitu:

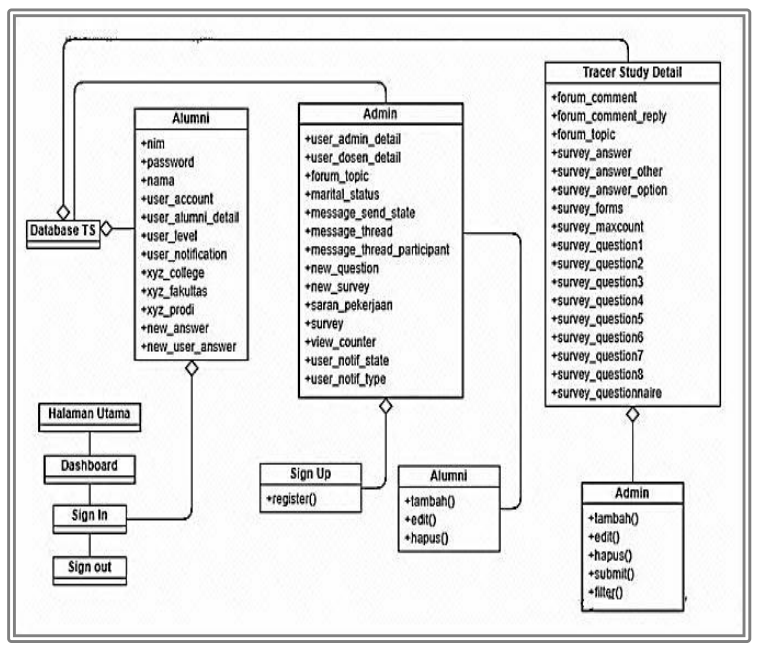

Gambar 2.5 Class Diagram

\subsubsection{Arsitektur Aplikasi}

Pada tahapan Arsitektur Aplikasi dilakukan dengan menggunakan pemodelan diagram yaitu Activity Diagram untuk merancang aplikasi tracer study, seperti tertuang pada gambar diagram 2.6 berikut ini:

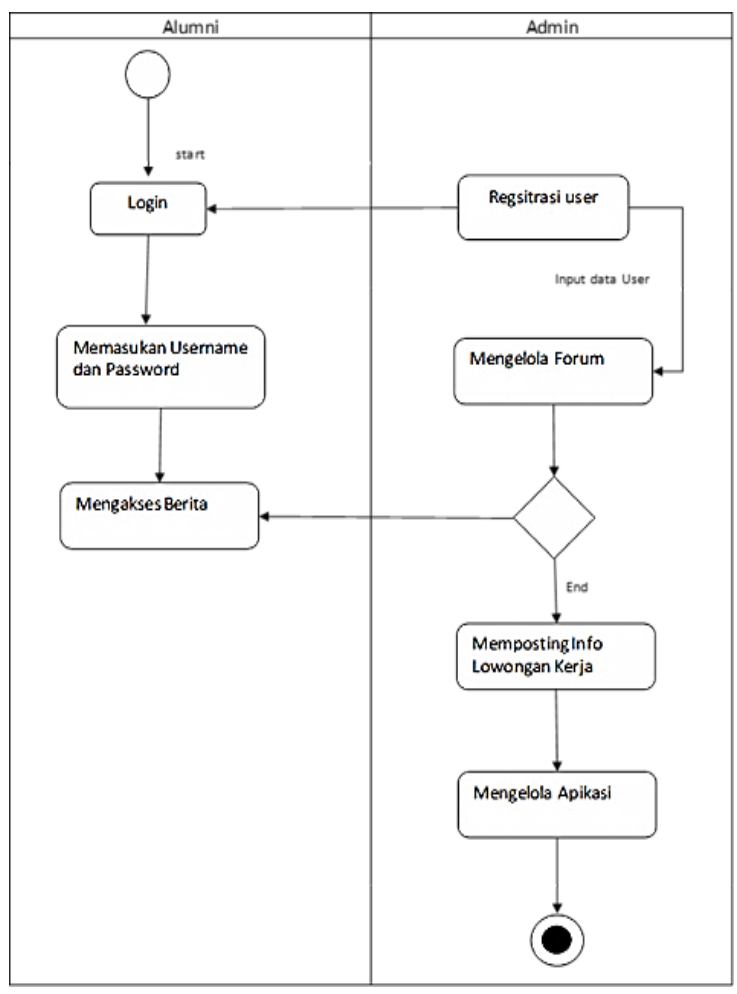

Gambar 2.6 Activity Diagram

\subsection{Phase D. Technology Architecture}

Terdapat beberapa tahapan di fase ini, Meliputi Gap Analysis Arsitektur Teknologi, Konfigurasi Jaringan Internal, Platform Aplikasi, dan Infrastructure Topology.

\subsubsection{Gap Analysis Arsitektur Teknologi}

Penggambaran dari hasil Gap Analysis arsitektur teknologi tersebut dapat dilihat pada tabel 2.6 berikut ini:

Tabel 2.6 Gap Analysis Arsitektur Teknologi

\begin{tabular}{|c|l|l|l|}
\hline No & $\begin{array}{l}\text { Arsitektur } \\
\text { Teknologi } \\
\text { saat ini }\end{array}$ & \multicolumn{1}{|c|}{$\begin{array}{c}\text { Solusi } \\
\text { Arsitektur } \\
\text { Teknologi }\end{array}$} & $\begin{array}{l}\text { Target } \\
\text { Arsitektur } \\
\text { Teknologi } \\
\text { Mendatang }\end{array}$ \\
\hline 1. & $\begin{array}{l}\text { Belum ada } \\
\text { komputer } \\
\text { yang } \\
\text { berfungsi } \\
\text { sebagai } \\
\text { local } \\
\text { server. }\end{array}$ & $\begin{array}{l}\text { Melakukan } \\
\text { penambahan } \\
\text { infrastruktur } \\
\text { jaringan dengan } \\
\text { mempertimbangka } \\
\text { n antara } \\
\text { kebutuhan proses } \\
\text { bisnis dengan } \\
\text { spesifikasi } \\
\text { perangkat keras } \\
\text { yang dibutuhkan. }\end{array}$ & $\begin{array}{l}\text { Tersedianya } \\
\text { komputer } \\
\text { yang } \\
\text { berperan } \\
\text { sebagi local } \\
\text { server untuk } \\
\text { SI Tracer } \\
\text { study. }\end{array}$ \\
& $\begin{array}{l}\text { Melakukan } \\
\text { penambahan }\end{array}$ & $\begin{array}{l}\text { Adanya } \\
\text { jaringan } \\
\text { komputer }\end{array}$ \\
\hline 2. & $\begin{array}{l}\text { Belum } \\
\text { adanya } \\
\text { jaringan }\end{array}$ & &
\end{tabular}




\begin{tabular}{|l|l|l|l|}
\hline $\begin{array}{l}\text { komputer } \\
\text { yang } \\
\text { dipergunak } \\
\text { an secara } \\
\text { khusus } \\
\text { untuk } \\
\text { pengelolaa } \\
\text { n tracer } \\
\text { study. }\end{array}$ & jaringan. & $\begin{array}{l}\text { yang secara } \\
\text { khusus untuk } \\
\text { pengelolaan } \\
\text { tracer study. }\end{array}$ \\
\hline 3. & & \\
Belum ada & & Melakukan & \\
pemanfaat & penambahan & Tersedianya \\
an & infrastruktur & sms/whatsap \\
teknologi & teknologi sms & p gateway \\
sms & gateway server & dan sistem \\
gateway & dan sistem & informasinya \\
dalam & informasinya. & . \\
pengelolaa & & \\
n tracer & & \\
study. & & \\
\hline
\end{tabular}

\subsubsection{Konfigurasi Jaringan Internal (Pengelolaan Tracer study)}

Pada gambar 2.7 berikut ini merupakan gambaran dari konfigurasi jaringan saat ini pada pengelolaan tracer studi AMIK XYZ.

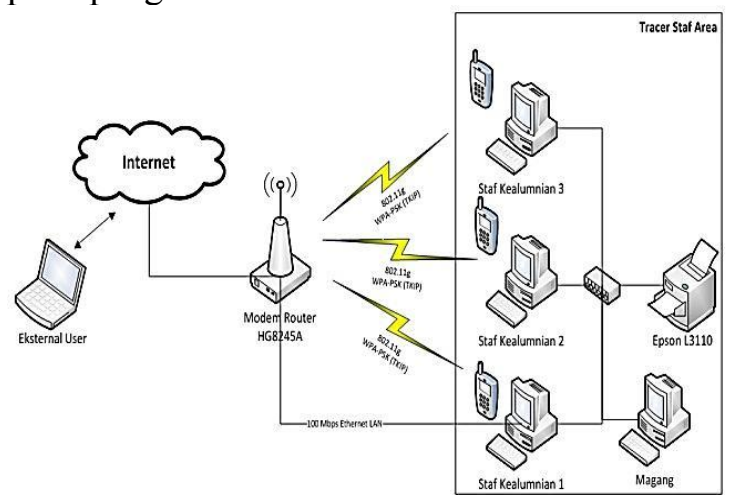

Gambar 2.7 Jaringan Existing

Untuk konfigurasi jaringan internal yang diusulkan dapat dilihat pada gambar, Pada jaringan yang akan diusulkan adalah sebagai berikut:

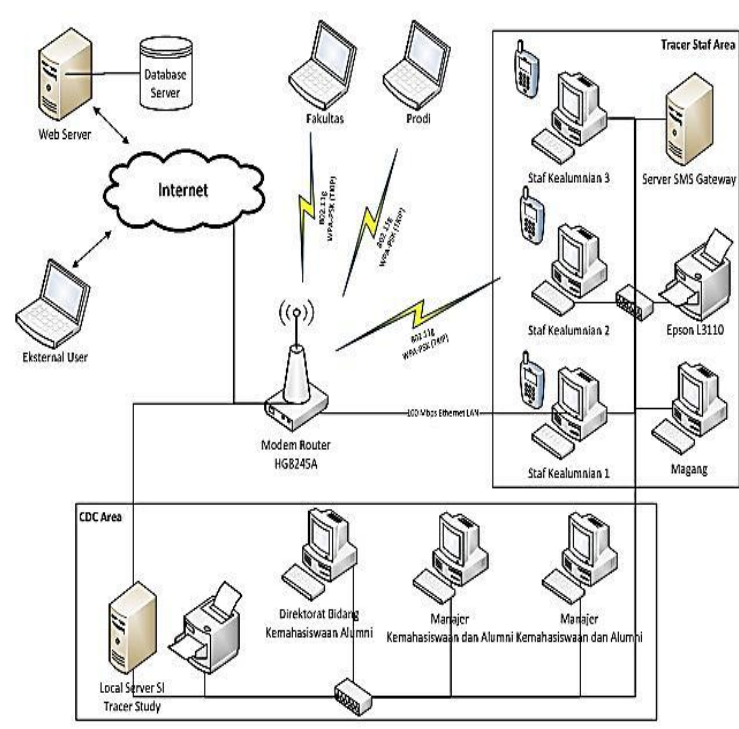

Gambar 2.8 Jaringan Usulan

\subsubsection{Platform Aplikasi}

Tabel 2.7 Platform Aplikasi (Usulan)

\begin{tabular}{|c|c|c|}
\hline \multicolumn{3}{|c|}{1 Hardware } \\
\hline & $\begin{array}{ll}- & \text { Personal Computer } \\
& \text { (PC) } \\
- & \text { Server } \\
\text { - } & \text { Jaringan Internet } \\
\text { - } & \text { Laptop } \\
- & \text { Printer }\end{array}$ & $\begin{array}{ll}\text { - } & \text { Processor Core } \\
& \text { i3 2,5 Ghz } \\
\text { - } & \text { DNS Server } \\
\text { - } & \text { Indihome } \\
& \text { 10Mbps } \\
\text { - } & \text { Lenovo Core i3 } \\
\text { - } & \text { Epson L31XX }\end{array}$ \\
\hline 2 & Software & \\
\hline & $\begin{array}{ll}- & \text { XAMPP. } \\
- & \text { Notepad }++ \\
& \text { Sublime Editor. } \\
- & \text { Google Chrome }\end{array}$ & \\
\hline
\end{tabular}

\subsubsection{Infrastucture Topology}

Berdasarkan kondisi saat ini, layanan jaringan yang akan diberikan berupa LAN, internet, basis data server, dan aplikasi server. Untuk layanan jaringan LAN digunakan oleh user untuk berbagi sumber daya seperti printer dan pertukaran data.

\subsubsection{Prototype Implementasi}

Prototype implementasi adalah model dari pengimplementasian perancangan maupun sub-sub sistem yang diuraikan pada tahapan sebelumnya. 


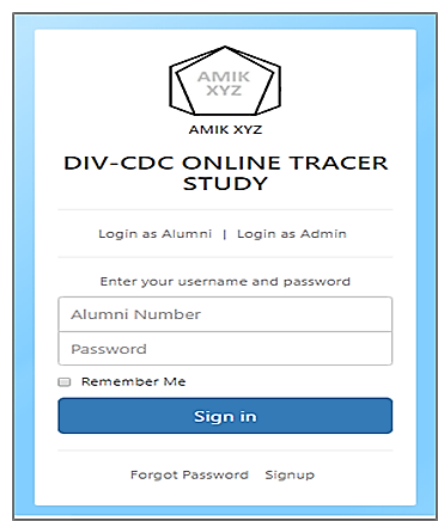

Gambar 2.9 Menu Login Sistem Tracer study

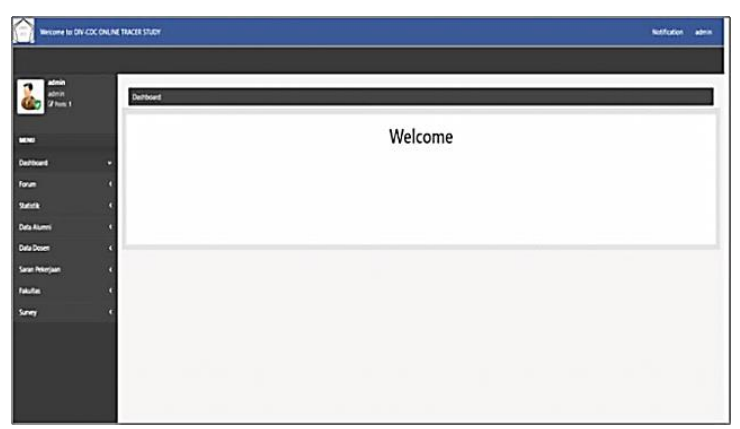

Gambar 2.10 Halaman Utama Admin (Dashboard)

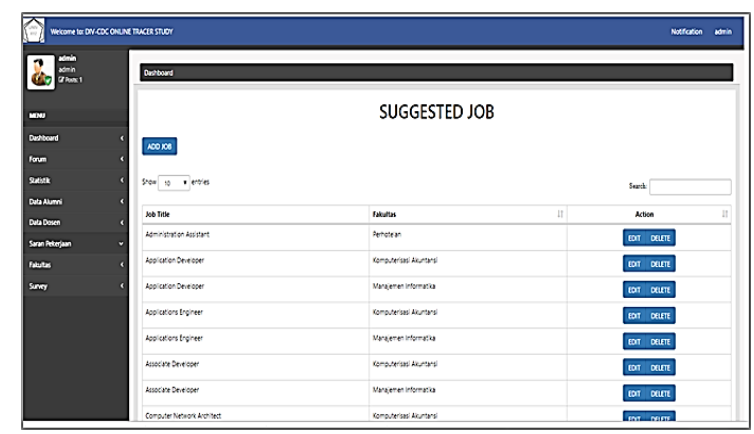

Gambar 2.11 Tampilan Saran Pekerjaan

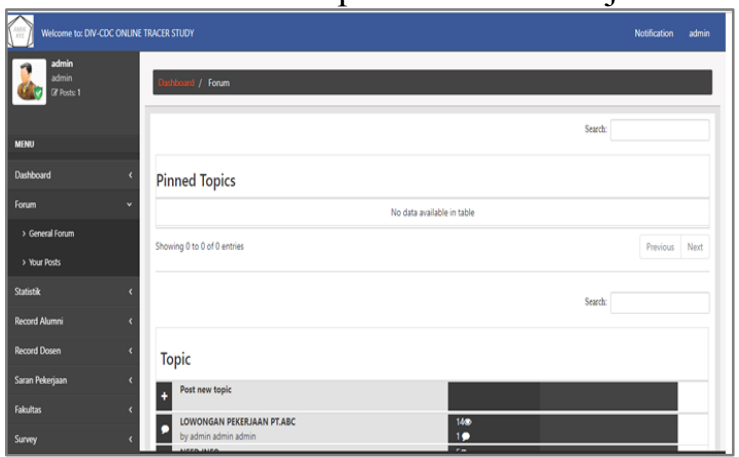

Gambar 2.12 Forum Diskusi

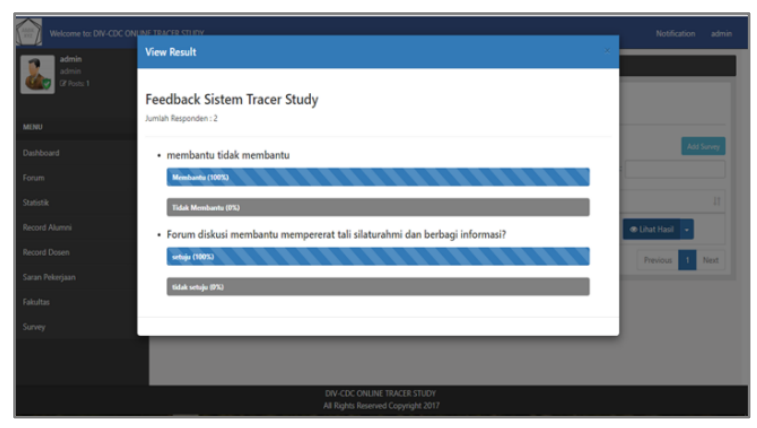

Gambar 2.13 Survey Kuisioner

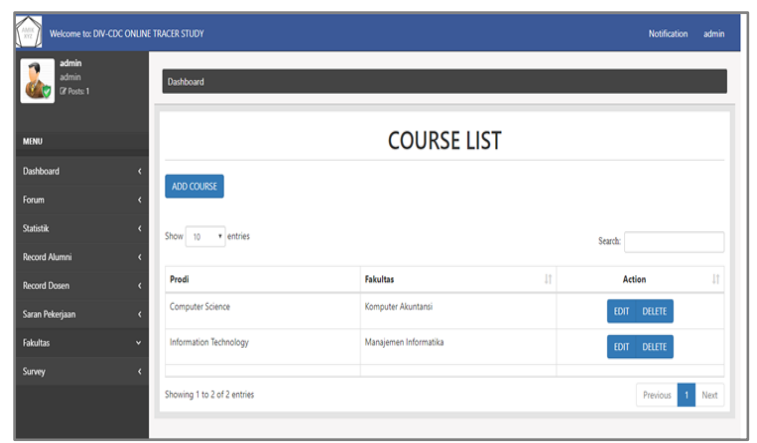

Gambar 2.14 Program Studi

\subsection{Hasil Uji Korelasi}

Pada tahapan ini dilakukan penyebaran kuesioner yang dilakukan kepada alumni AMIK XYZ dengan jumlah responden 25 orang mahasiswa dan mahasiswi lulusan kampus tersebut, instrumen kuesioner menggunakan skala likert. Kemudian dilakukan tabulasi hasil dari jawaban responden, untuk selanjutnya di uji frekuensi hasil. Pada tahap terakhir dilakukan uji korelasi Rho Spearman antara pengembangan arsitektur pada sistem informasi tracer study menggunakan metode togaf dengan prototype tracer study yang merupakan hasil dari pengembangan dengan metode togaf, tersaji pada tabel 2.8 dibawah ini:

Tabel 2.8 Korelasi Rho Spearman

\begin{tabular}{|c|c|l|}
\hline \multicolumn{3}{|c|}{ Correlations } \\
\hline & Pengemba & Prototype \\
ngan & SI Tracer \\
& arsitektur & Study \\
& pada SI & AMIK \\
& Tracer & XYZ \\
& Study & \\
& dengan & \\
& metode & \\
& Togaf & \\
\hline
\end{tabular}




\begin{tabular}{|c|c|c|c|c|}
\hline \multirow[t]{6}{*}{$\begin{array}{l}\text { Spear } \\
\text { man's } \\
\text { rho }\end{array}$} & \multirow{3}{*}{$\begin{array}{l}\text { Pengemba } \\
\text { ngan } \\
\text { arsitektur } \\
\text { pada SI } \\
\text { Tracer } \\
\text { Study } \\
\text { dengan } \\
\text { metode } \\
\text { Togaf } \\
\end{array}$} & $\begin{array}{l}\text { Correl } \\
\text { ation } \\
\text { Coeffi } \\
\text { cient } \\
\end{array}$ & 1,000 &, $700^{* *}$ \\
\hline & & $\begin{array}{l}\text { Sig. } \\
(2- \\
\text { tailed) }\end{array}$ & & ,000 \\
\hline & & $\mathrm{N}$ & 25 & 25 \\
\hline & \multirow[t]{3}{*}{$\begin{array}{l}\text { Prototype } \\
\text { SI Tracer } \\
\text { Study } \\
\text { AMIK } \\
\text { XYZ }\end{array}$} & $\begin{array}{l}\text { Correl } \\
\text { ation } \\
\text { Coeffi } \\
\text { cient } \\
\end{array}$ &, $700^{* *}$ & 1,000 \\
\hline & & $\begin{array}{l}\text { Sig. } \\
(2- \\
\text { tailed) }\end{array}$ & ,000 & \\
\hline & & $\mathrm{N}$ & 25 & 25 \\
\hline
\end{tabular}

Berdasarkan hasil analisa dengan uji rho spearman seperti pada tabel di atas maka dapat dilihat bahwa nilai korelasi antara pengembangan arsitektur pada sistem informasi tracer study menggunakan metode togaf (Variabel X) dengan prototype arsitektur pada sistem informasi tracer study yang merupakan hasil dari pengembangan dengan metode togaf (Variabel Y) diperoleh angka koefisien sebesar $r=0.700$, nilai ini berada di antara nilai $0,51-0,75$, yang artinya tingkat kekuatan hubungan (korelasi) adalah kuat, angka koefisien korelasi bernilai positif = 0,700 sehingga hubungan kedua variabel bersifat searah (jenis huubungan searah), artinya jika pengembangan arsitektur pada sistem informasi tracer study menggunakan metode togaf yang diimplementasikan melalui prototype tracer study yang merupakan hasil dari pengembangan dengan metode togaf semakin baik maka akan berdampak baik pada sistem AMIK XYZ

Kontribusi variabel $\mathrm{X}$ terhadap variabel $\mathrm{Y}$ dapat dilihat berdasarkan nilai koefisien determinasi $(\mathrm{Kd})$ sebagai berikut:

$$
\begin{aligned}
& \mathrm{Kd}=\mathrm{r} 2 \times 100 \% \\
& \mathrm{Kd}=(0,700) 2 \times 100 \% \\
& \mathrm{Kd}=0,49 \%
\end{aligned}
$$

Nilai koefisien determinasi $(\mathrm{Kd})$ tersebut menunjukan besarnya kontribusi dari variabel (X) yaitu model arsitektur TOGAF Framework pada SI tracer study dengan prototype SI tracer study berbasis web yang diimplmentasikan pada sistem AMIK XYZ (Y) sebesar 0,49 \% sedangkan sisanya sebesar $99,51 \%$ dipengaruhi oleh variabel-variabel lain diluar variabel model arsitektur TOGAF Framework pada SI tracer study dengan prototype hasil.

\section{KESIMPULAN}

Kesimpulan yang dapat diuraikan dari tahap pekerjaan pemodelan arsitektur enterprise adalah sebagai berikut:

1. Pemodelan bisnis tracer study memiliki aktivitas utama yaitu pendataan alumni dan pengelolaan serta penyampaian informasi lowongan kerja.

2. Enterprise architecture yang terbentuk bisa digunakan sebagai monitoring terhadap keberhasilan alumni dalam mendapatkan pekerjaan.

3. Penelitian ini memfokuskan pada pemodelan arsitektur terhadap aktivitas bisnis dengan lingkup pemodelan bisnis, data, aplikasi dan teknologi.

\section{DAFTAR PUSTAKA}

[1] Syafiq, Ahmad \& Fikawati, Sandra. (2012). Indonesia:UI Press

[2] R. Muhammad, dkk, 2018, Analisis Dan Perancangan Sistem Informasi Tracer Study Berbasis WEB, Jurnal Infomedia, Vol. 3 No. 2.

[3] Almasyhur, A.K., dkk, 2018, Pengembangan Aplikasi Mobile Tracer Study Menggunakan Platform Android, Jurnal Pengembangan Teknologi Informasi dan Ilmu Komputer, Vol. 2, No. 11.

[4] Kartika Indayani, dkk, 2016, Aplikasi Mobile Alumni Center (Studi Kasus di Institut Sains \& Teknologi AKPRIND), Jurnal SCRIPT Vol.3 No. 2

[5] Astomo, Dikot Sugeng, 2017, Pembangunan Aplikasi Pencarian Alumni Berbasis Android dengan Memanfaatkan API Sosial Media, Skripsi. Program Studi Teknik Informatika Fakultas Teknik dan Ilmu Komputer, Bandung.

[6] Jogiyanto, H.M., 2005, Analisa dan Desain Sistem Informasi: Pendekatan Terstruktur Teori dan Praktik Aplikasi Bisnis, ANDI, Yogyakarta 
[7] Harald Schomburg, Handbook for Graduate Tracer Study. Universitas Kassel : Moenchebergstrasse Kassel, Germany: Wissenschaftliches Zentrum fur Berufsund Hochschulforschung, 2003.

[8] The Open Group. (2009). TOGAF version 9. The Open Group

[9] Hakim, Lukmanul dan Uus Musalini. 2004. Cara Cerdas Menguasai Layout, Desain dan Aplikasi Web. Jakarta: PT Elex Media Komputindo. 